\title{
Detection of Piscirickettsia salmonis in fish tissues by an enzyme-linked immunosorbent assay using specific monoclonal antibodies
}

\author{
Juan Aguayo, Alvaro Miquel, Naddim Aranki, Adolfo Jamett, \\ Pablo D. T. Valenzuela, Luis O. Burzio* \\ Bios Chile Ingeniería Genética S.A., Fundación Ciencia para la Vida and Millennium Institute \\ for Fundamental and Applied Biology, Avda Marathon 1943, Nuñoa, Santiago, Chile
}

\begin{abstract}
An enzyme-linked immunosorbent assay (ELISA) for the detection of Piscirickettsia salmonis in fish tissue samples was developed. The test uses a combination of different monoclonal antibodies specific against $P$. salmonis in the capture step of the assay. The antibodies 7G4,6E2 and $2 \mathrm{C} 1$ chosen for the capture step are bound to the solid support with an adhesive protein purified from a bivalve mollusc, resulting in a high yield of adsorption and binding stability. The monoclonal antibody 7G4, used as a second antibody, is conjugated to horseradish peroxidase. The resulting ELISA test detected 7 different isolates of $P$. salmonis and does not cross-react with several other fish pathogens, revealing a high specificity and sensitivity. The test also detects $P$. salmonis in kidney tissue of infected coho salmon with $98 \%$ correlation with the immunofluorescence assay.
\end{abstract}

KEY WORDS: ELISA · Salmon diseases · Piscirickettsia salmonis · Piscirickettsiosis · Monoclonal antibodies

Resale or republication not permitted without written consent of the publisher

\section{INTRODUCTION}

Piscirickettsia salmonis, the etiological agent of piscirickettsiosis, was the first rickettsia-like bacterium isolated from an aquatic poikilotherm (Fryer et al. 1990, Garcés et al. 1991, Lannan \& Fryer 1993). This is an economically significant pathogen, responsible for extensive mortalities in the aquaculture industry. $P$. salmonis, a Gram-negative obligate intracellular bacterium, was first observed in diseased coho salmon (Oncorhynchus kizutch) from a saltwater net pen in the south of Chile (Bravo \& Campos 1989). It is known that the pathogen is geographically more widespread than initially suspected, and a piscirickettsia-like organism has been observed in Ireland (Rodger \& Drinan 1993), Scotland (Grant et al. 1996), Norway (Olsen et al. 1997) and the Pacific coast of Canada (Brocklebank et al.

${ }^{*}$ Corresponding author. E-mail: lburzio@bioschile.cl
1993). Initially, it was thought that $P$. salmonis was confined to the saltwater stage of the salmonid life cycle, but the pathogen has now been isolated from juvenile coho salmon and rainbow trout (Oncorhynchus mykiss) reared only in freshwater (Gaggero et al. 1995).

Piscirickettsia salmonis causes a systemic infection that targets the kidney, liver, spleen, heart, brain, intestine, ovary and gills of salmonids (Cvitanich et al. 1991). The coccoid bacterium ranges in diameter from 0.5 to $1.5 \mu \mathrm{m}$ and is found within cytoplasmic vacuoles in the cells of infected tissues (Bravo \& Campos 1989, Fryer et al. 1992). The pathogen was initially isolated from the kidney of a diseased adult coho salmon and successfully cultured in a cell line derived from the chinook salmon (Oncorhynchus tshawytscha) embryos known as CHSE-214 cells (Fryer et al. 1990). Depending on the number of bacterial cells inoculated, the cytopathic effect (CPE) induced by the pathogen requires approximately $5 \mathrm{~d}$ incubation. This delay prolongs the diagnosis of the disease. There are several 
reports describing detection of $P$. salmonis with immunofluorescence assays using polyclonal antibodies conjugated with fluorescein isothiocyanate (Lannan et al. 1991, Barnes et al. 1998). Recently, we have developed a panel of monoclonal antibodies with high sensitivity and specificity like those tested in an immunofluorescence assay (Jamett et al. 2001). These monoclonal antibodies react with several isolates of $P$. salmonis, and the coccoid immunofluorescent shapes suggest that the antibodies recognize membraneassociated antigens (Jamett et al. 2001). This report describes the development of a highly specific sandwich enzyme-linked immunosorbent assay (ELISA), based on the use of monoclonal antibodies in the capture step of the assay and as a secondary antibody conjugated with horseradish peroxidase.

\section{MATERIALS AND METHODS}

In addition to Piscirickettsia salmonis LF-89 (ATCC VR 1361), several other isolates of $P$. salmonis obtained from different places in the south of Chile were used. The names of these isolates and their origins are as follows: (1) an isolate from the kidney of steelhead trout from Calbuco, Puerto Montt, obtained by Fundación Chile and named P. salmonis-Fundación Chile; and (2) isolates from the kidney of coho salmon from Pargua and Ralún, Puerto Montt, obtained by Aquatic Health Laboratories and referred to as P. salmonis-Aquatic Health, Ralún 14 and Ralún 17, 052 and L047. A bank of support inocula was prepared from the P. salmonis isolates by resuspending infected CHSE-214 lysates in a mixture of $10 \%$ dimethylsulfoxide in fetal calf serum and storing them in liquid nitrogen.

To determine the specificity of the ELISA assay, several bacteria maintained and grown as described previously (Jamett et al. 2001) were used as antigens (see Table 1).

Growth and purification of Piscirickettsia salmonis. P. salmonis LF-89 and other isolates listed above were continuously propagated in the chinook salmon embryo cell line CHSE-214 (CRL 1681 ATCC) (Lannan et al. 1984) using antibiotic-free minimal essential medium (MEM) plus 5\% bovine serum as described elsewhere (Fryer et al. 1990, Jamett et al. 2001).

The titer of Piscirickettsia salmonis was determined using a plaque formation assay method (Lannan et al. 1984). Briefly, serial dilutions of $P$. salmonis were plated on fresh monolayers of CHSE-214 cells in 24well plates and incubated at $16^{\circ} \mathrm{C}$ for $24 \mathrm{~h}$. After the attachment of $P$. salmonis to the cells, the culture was overlayered with $0.7 \%$ methylcellulose in MEM. Plates were incubated at $16^{\circ} \mathrm{C}$ for $8 \mathrm{~d}$ and the number of plaques determined under phase microscopy.
Piscirickettsia salmonis was purified using Percoll density gradient centrifugation (Jamett et al. 2001). The final pellet of purified bacterium was suspended in a solution containing $50 \mathrm{mM}$ Tris- $\mathrm{HCl}, \mathrm{pH}$ 7.5, $200 \mathrm{mM}$ $\mathrm{NaCl}$, and the concentration of protein was measured (Smith et al. 1985). To determine the number of bacterial cells $\mathrm{ml}^{-1}$, serial dilutions in the Tris-saline solution were counted under phase microscopy in a Neubauer chamber. In this procedure, $1 \mathrm{mg}$ of protein corresponds to $3.8 \times 10^{9}$ P. salmonis cells (Jamett et al. 2001)

Monoclonal antibodies. Seven monoclonal antibodies specific to Piscirickettsia salmonis and referred to as $1 \mathrm{G} 9,5 \mathrm{G} 1,7 \mathrm{G} 11,7 \mathrm{G} 4,2 \mathrm{C} 1,8 \mathrm{~F} 5$ and $6 \mathrm{E} 2$ were produced as ascitic fluid and then purified by chromatography in a Protein G Sepharose column (Pharmacia; Jamett et al. 2001).

The monoclonal antibody $7 \mathrm{G} 4$ was conjugated with horseradish peroxidase according to a procedure described by Tijssen \& Kurstak (1984) with a few modifications. Briefly, $1 \mathrm{ml}$ of a solution containing $4 \mathrm{mg} \mathrm{ml}^{-1}$ of the purified antibody 7G4 was dialyzed overnight against $0.1 \mathrm{M}$ sodium carbonate at $\mathrm{pH}$ 9.1. Before the coupling reaction, horseradish peroxidase was oxidized by incubating a solution containing $1 \mathrm{mg} \mathrm{ml}^{-1}$ of the enzyme in $0.1 \mathrm{M}$ sodium carbonate, $\mathrm{pH} 8.2$, with 1 volume of $8 \mathrm{mM}$ sodium periodate for $2 \mathrm{~h}$ at room temperature. The oxidizing reaction was stopped by the addition of 1 volume of sodium carbonate, $\mathrm{pH}$ 9.1. The reaction between the antibody and peroxidase was done by adding $500 \mu \mathrm{l}$ of a solution containing $2 \mathrm{mg}$ of the dialyzed antibody $7 \mathrm{G} 4$ and $150 \mu \mathrm{l}$ of the oxidized peroxidase to a glass column containing $100 \mathrm{mg}$ of dry Sephadex G-25. The mixture was incubated at room temperature in the dark for $3 \mathrm{~h}$ and the column was eluted with sodium carbonate $\mathrm{pH}$ 9.1. Fractions of $0.5 \mathrm{ml}$ were collected and, after determining the absorbance at $280 \mathrm{~nm}, 5$ fractions totaling a final pool of $2.5 \mathrm{ml}$ were mixed with $125 \mu \mathrm{l}$ of a solution containing $5 \mathrm{mg} \mathrm{ml}^{-1}$ of sodium tetraborohydrate in $0.1 \mathrm{mM} \mathrm{NaOH}$. The mixture was maintained for $30 \mathrm{~min}$ in the dark at room temperature, and then $250 \mu \mathrm{l}$ of $20 \mathrm{mg} \mathrm{ml} \mathrm{m}^{-1}$ glycine was added and incubated in the same condition for an additional $30 \mathrm{~min}$. Finally, $400 \mu \mathrm{l}$ of a fresh solution of sodium tetraborohydrate was added and incubated for $30 \mathrm{~min}$ in the dark. The conjugate was dialyzed overnight against 21 of phosphate-buffered saline (PBS) at $\mathrm{pH} 7.0$ at $4^{\circ} \mathrm{C}$ and stored at $-20^{\circ} \mathrm{C}$.

ELISA. Polystyrene microtiter plates (PolySorp) were coated with the adhesive polyphenolic protein purified from the mussel Aulacomya ater (Burzio et al. 1996). Briefly, $100 \mu \mathrm{l}$ of a $3 \mu \mathrm{g} \mathrm{ml}^{-1}$ solution of the adhesive in $0.1 \%$ acetic acid was applied to each well and incubated for $20 \mathrm{~min}$ at room temperature. The acidic solution was discarded and the plate was air dried at $37^{\circ} \mathrm{C}$ for $1 \mathrm{~h}$. 
To bind each monoclonal antibody to the coated plate, $100 \mu \mathrm{l}$ of antibody solution in PBS containing between 0.75 and $12 \mu \mathrm{g} \mathrm{ml}^{-1}$ of protein was applied to each well and incubated for $2 \mathrm{~h}$ at $37^{\circ} \mathrm{C}$. After discarding the solution, the plate was washed once with distilled water and then blocked with a solution containing $2 \%$ casein and $2 \%$ sucrose in PBS for $2 \mathrm{~h}$ at room temperature. The blocking solution was discarded, and the plate was air dried for $2 \mathrm{~h}$ at $37^{\circ} \mathrm{C}$ and stored at $4^{\circ} \mathrm{C}$ in a sealed plastic envelope with desiccant.

To prepare the tissue extract, about $200 \mathrm{mg}$ of salmon kidney was transferred to a plastic bag together with 2 volumes (w/v) of a solution containing $0.3 \mathrm{M}$ sucrose, $0.15 \mathrm{M} \mathrm{NaCl}, 5 \mathrm{mM} \mathrm{MgCl}_{2}, 1 \mathrm{mM} \mathrm{CaCl}_{2}$ and $10 \mathrm{mM}$ sodium phosphate buffer at $\mathrm{pH}$ 7.5. The bag was sealed to avoid contamination and the kidney was macerated with a spatula. The macerate was transferred to a sterile Eppendorf tube and centrifuged at $2000 \times g$ for $5 \mathrm{~min}$. Then, $100 \mu \mathrm{l}$ of the supernatant was applied in duplicate to wells of the microplate. In separate wells, $100 \mu \mathrm{l}$ of a suspension of Piscirickettsia salmonis or $100 \mu \mathrm{l}$ of PBS was added. After incubation for $1 \mathrm{~h}$ at $37^{\circ} \mathrm{C}$, the samples were discarded and the plate was washed 3 times with a Tris-saline-Tween solution (25 mM Tris- $\mathrm{HCl}, \mathrm{pH}$ 8.0, $150 \mathrm{mM} \mathrm{NaCl}$ and $0.05 \%$ Tween 20). Then, $100 \mu$ l of the antibody $7 \mathrm{G} 4$ conjugated to peroxidase diluted with a solution of $2 \%$ casein and $2 \%$ sucrose in PBS was added to each well and incubated for $30 \mathrm{~min}$ at $37^{\circ} \mathrm{C}$. The plate was washed 4 times with Tris-saline-Tween solution, followed by the addition of $50 \mu \mathrm{l}$ of tetramethylbenzidine (TMB) and $50 \mu \mathrm{l}$ of hydrogen peroxide at $3 \%$ (KPL), and incubated at room temperature for $30 \mathrm{~min}$ in the dark. The color reaction was stopped with $100 \mu \mathrm{l}$ of $3 \mathrm{~N} \mathrm{H}_{2} \mathrm{SO}_{4}$ and the absorbance at $450 \mathrm{~nm}$ was determined with a Titertek Multiskan MK II plate reader(Labsystems).

Immunofluorescence. Indirect immunofluorescence (IFAT) of kidney tissues was carried out with the monoclonal antibody $7 \mathrm{G} 4$ as described by Jamett et al. (2001).

\section{RESULTS}

Initially, we designed experiments to establish the optimal conditions for coupling horseradish peroxidase to antibodies 7G4, 2C1, 8F5 and 6E2. In general all 4 antibodies revealed good activity in the ELISA, although a progressive increase in the absorbance of the negative controls was observed with older preparations, especially with the 8F5 antibody. This problem was resolved by introducing an incubation step with glycine after the first reduction with tetraborohydrate (Tijssen \& Kurstak 1984). The conjugates prepared as described were stable for 6 mo and showed no increase in ab- sorbance with the negative controls with PBS alone or with kidney tissue from healthy salmon. Because of the high yield and the stability of 7G4, this antibody was selected as the secondary antibody for the test.

To select the best antibody for the capture step of the ELISA, microtiter plates were activated with $5 \mu \mathrm{g} \mathrm{ml}^{-1}$ of the different antibodies and assayed with $150 \mathrm{ng}$ of purified Piscirickettsia salmonis. As shown in Fig. 1A, the monoclonals 2C1, 6E2, 7G4 and 8F5 exhibited good capture activity when assayed with the 7G4 antibody conjugated with peroxidase. In contrast, antibodies 1G9, 5G1 and 7G11 revealed poor or no activity in the capture step.

Next, the concentration of antibody used to activate the microtiter plates was determined. The wells were activated with $100 \mu \mathrm{l}$ of different concentrations of $2 \mathrm{C} 1$, $6 \mathrm{E} 2$ or $7 \mathrm{G} 4$, ranging from 12 to $0.75 \mu \mathrm{g} \mathrm{ml}^{-1}$. The monoclonal antibody 8F5 was not used due to stability problems. As shown in Fig. 1B, the optimal concentration of antibody was between 6 and $3 \mu \mathrm{g} \mathrm{ml}^{-1}$ with a decrease at higher antibody concentrations. Therefore, all further experiments were carried out with plates activated with $100 \mu \mathrm{l}$ of an antibody solution containing $5 \mu \mathrm{g} \mathrm{ml}^{-1}$. The decrease in absorbance observed at higher concentrations of antibody might be due to a zone effect. The use of plates pre-coated with the mussel adhesive enhanced the immobilization of antibodies to the solid support, resulting in more antibodies bound to the plate and probably inducing a zone effect (Burzio et al. 1996). All the following results were obtained with plates activated with a solution containing $5 \mu \mathrm{g} \mathrm{ml}^{-1}$ of the antibody $2 \mathrm{C} 1$.

To determine the best incubation time during the capture and secondary antibody steps, plates were activated with the antibody $2 \mathrm{C} 1$ and assayed with $400 \mathrm{ng}$ of Piscirickettsia salmonis (Fig. 2). The incubation time was between 15 and 90 min for the capture step and between 15 and 60 min for the secondary antibody step. The absorbance obtained after 60 min incubation with the bacteria was about $90 \%$ of the value after $90 \mathrm{~min}$ incubation. On the other hand, after a 60 min incubation time in the capture step, the absorbance obtained after incubating with the secondary antibody between 30 and 60 min was very similar (Fig. 2). Therefore, and considering signal quality and time efficiency, incubation times for the capture and secondary antibody steps were fixed at 60 and $30 \mathrm{~min}$, respectively. The color reaction with peroxidase substrate was standardized to 30 min. Under these conditions, the detection limit was about $15 \mathrm{ng}$ of purified $P$. salmonis protein where the absorbance was about 3 times the value of the negative control without bacteria (optical density [OD] 0.060 vs 0.20) (Fig. 3). The saturation level was achieved with $300 \mathrm{ng}$ of $P$. salmonis protein (Fig. 3).

Specificity of the ELISA test using several fish pathogens was also determined. The absorbance ob- 

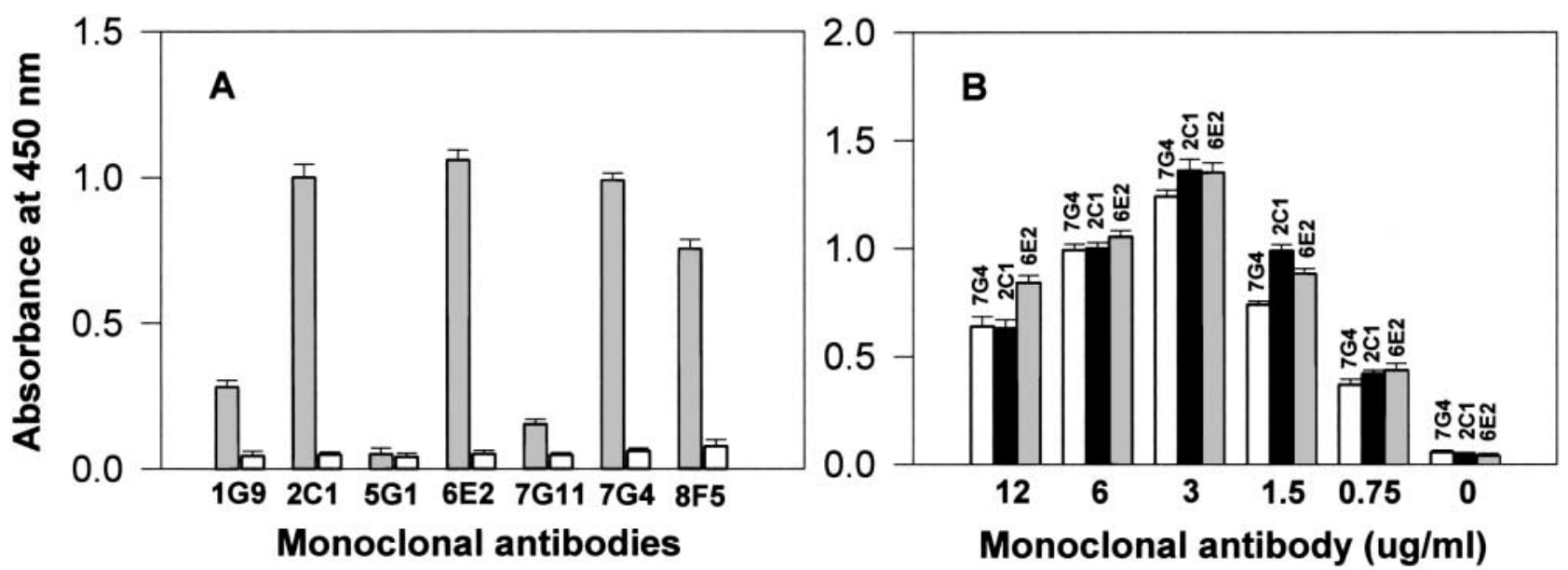

Fig. 1. Performance of different monoclonal antibodies in the capture step of the enzyme-linked immunosorbent assay (ELISA). (A) Plates were activated with $100 \mu \mathrm{l}$ containing $5 \mu \mathrm{g} \mathrm{ml}^{-1}$ well ${ }^{-1}$ of the indicated antibodies (see 'Materials and methods'). The assay was carried out with $100 \mu \mathrm{l}$ containing approximately $100 \mathrm{ng}$ of Piscirickettsia salmonis (grey columns) or phosphatebuffered saline (PBS) (white columns). The monoclonal antibody 7G4 conjugated with peroxidase was used at a final concentration of $2 \mu \mathrm{g} \mathrm{ml}^{-1}$. Each value is the average of 4 determinations and the vertical bars correspond to the standard deviation. (B) Optimization of the activation of the plate with monoclonal antibodies. Plates were activated with either 7G4, 2C1 or 6E2 at the indicated concentrations and visualized with the peroxidase-7G4 conjugate. The assay was carried out with $200 \mathrm{ng}$ of $P$. salmonis and the negative control was PBS. Each value is the average of 4 determinations, and the vertical bars correspond to the standard deviation

tained with several salmon pathogens was about 0.07 at $450 \mathrm{~nm}$, similar to the value obtained with the negative control without Piscirickettsia salmonis when the monoclonal antibodies $2 \mathrm{C} 1$ and $6 \mathrm{E} 2$ were used in the cap-

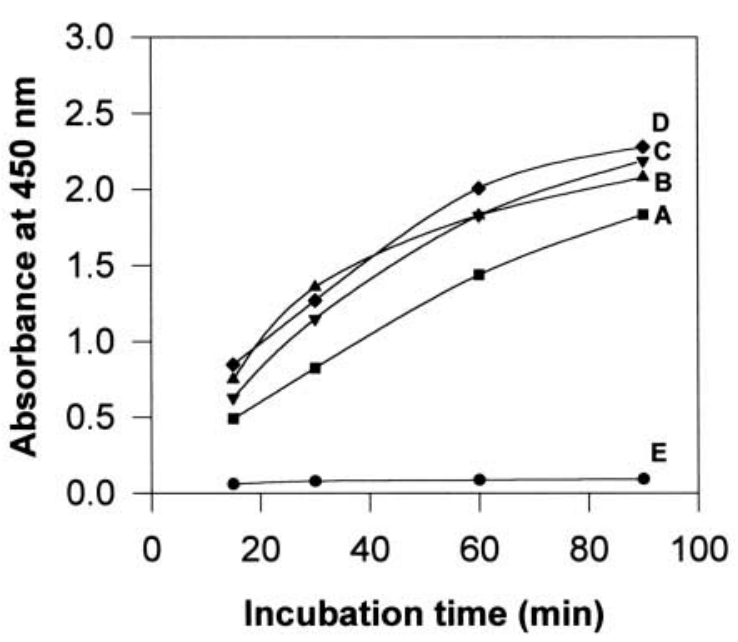

Fig. 2. Optimal incubation time for the capture and secondary antibody steps. Plates activated with $5 \mu \mathrm{g}$ well ${ }^{-1}$ of antibody 2C1 were assayed with 400 ng of Piscirickettsia salmonis and incubated for 15, 30, 60 and 90 min at $37^{\circ} \mathrm{C}$. After washing, $100 \mu \mathrm{l}$ of the secondary antibody was added and incubated for 15 min (Curve A), 30 min (Curve B), 45 min (Curve C) and 60 min (Curve D) at $37^{\circ} \mathrm{C}$. Plates were washed and the color reaction was developed for $30 \mathrm{~min}$ at room temperature and in the dark. Curve E shows the negative control incubated for 60 min with buffer followed by 30 min incubation with the secondary antibody ture step (Table 1). In contrast, the absorbance obtained with $500 \mathrm{ng}$ of $P$. salmonis was between 2.8 and $3.0 \mathrm{ab}-$ sorbance units (Table 1). The monoclonal antibody 8F5 was not further used since the absorbance of the negative control and that obtained with the other salmon pathogens was significantly higher (Table 1).

Six isolates obtained from different salmon farming centers from the south of Chile were assayed using the ELISA test. This assay was carried out with ca. $100 \mathrm{ng}$ well ${ }^{-1}$ of protein extract of each isolate in order to visualize possible differences among the different bacteria. As shown in Fig. 4, the absorbance ranged between 0.6 and $0.9 \mathrm{OD}$ with the isolates as compared to the negative control, which was 0.09 OD.

To confirm the assay with salmon tissue, the ELISA was carried out with 130 kidney samples of infected and uninfected salmon. About $200 \mathrm{mg}$ of tissue was processed and assayed as described. In parallel, smears were prepared with the same tissues and tested for the presence of Piscirickettsia salmonis by IFAT using the 7G4 monoclonal antibodies (Jamett et al. 2001). The data in Table 2 reveal a close correlation between the results obtained by immunofluorescence and those obtained by ELISA. From the 130 samples tested, 54 were confirmed as positive by the IFAT assay. The sandwich ELISA correctly detected 53 samples as positive, corresponding to a sensitivity of $98 \%$. The cut-off for the assay, defined as 3 times the average absorbance of the negative controls, was 0.27 . The specificity of the ELISA was $100 \%$ since all the samples that were negative by the IFAT assay were confirmed as negative by the sandwich ELISA (Table 2). 


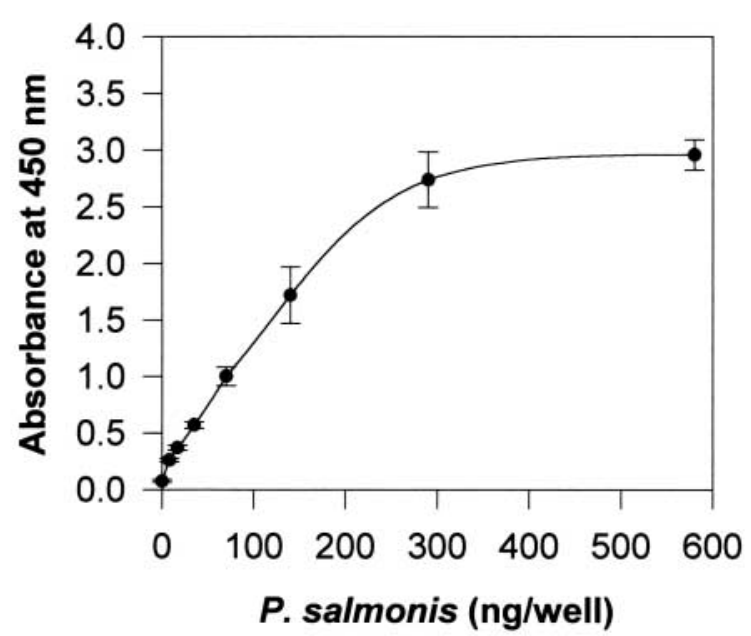

Fig. 3. Limit of detection of Piscirickettsia salmonis by the sandwich ELISA. The microtiter plates were activated with $100 \mu \mathrm{l}$ of $5 \mu \mathrm{g} \mathrm{ml}^{-1}$ of the antibody 2C1, and the ELISA was carried out with the indicated amount of $P$. salmonis. The second antibody was peroxidase-coupled $7 \mathrm{G} 4$ at a final concentration of $2 \mu \mathrm{g} \mathrm{ml}^{-1}$. Each point is an average of 4 different determinations, and the vertical bars correspond to the standard deviation

\section{DISCUSSION}

Recently we described the characterization of a panel of monoclonal antibodies specific against Piscirickettsia salmonis (Jamett et al. 2001). By IFAT, these antibodies yielded a bright coccoid and doughnutshaped fluorescence with several isolates of $P$. salmo-

Table 1. Specificity of monoclonal antibodies to Piscirickettsia salmonis determined by enzyme-linked immunosorbent assay (ELISA). A: absorbance. With the exemption of Piscirickettsia salmonis, the mean absorbance obtained with 8F5 was $0.126 \pm 0.011$, which was significantly different $(p=0.0001)$ from the mean absorbance of $0.075 \pm 0.006$ obtained with antibody 2C1. Each absorbance value is an average of 4 determinations

\begin{tabular}{|lccc|}
\hline Pathogenic bacteria & \multicolumn{3}{c|}{$\mathrm{A}_{450 \mathrm{~nm}}$} \\
& 2C1 & $6 \mathrm{E} 2$ & $8 \mathrm{~F} 5$ \\
\hline Yersinia ruckeri (ATCC) & 0.071 & 0.081 & 0.134 \\
Yersinia ruckeri (Lago Rupanco) & 0.062 & 0.074 & 0.134 \\
Yersinia ruckeri (Lago Llanquihue A) & 0.065 & 0.073 & 0.108 \\
Yersinia ruckeri (Lago Llanquihue B) & 0.060 & 0.069 & 0.126 \\
Yersinia ruckeri (Lago Ranco) & 0.067 & 0.070 & 0.113 \\
Aeromonas sobria & 0.076 & 0.085 & 0.130 \\
Aeromonas hydrophila & 0.059 & 0.080 & 0.148 \\
Aeromonas caviae & 0.062 & 0.077 & 0.130 \\
Pseudomonas fluorescences & 0.063 & 0.065 & 0.125 \\
Escherichia coli & 0.083 & 0.074 & 0.124 \\
Renibacterium salmoninarum & 0.074 & 0.073 & 0.118 \\
Vibrio salmonicida & 0.073 & 0.077 & 0.114 \\
Piscirickettsia salmonis & 2.882 & 3.207 & 3.092 \\
Negative control & 0.065 & 0.085 & 0.135 \\
& & & \\
\hline
\end{tabular}

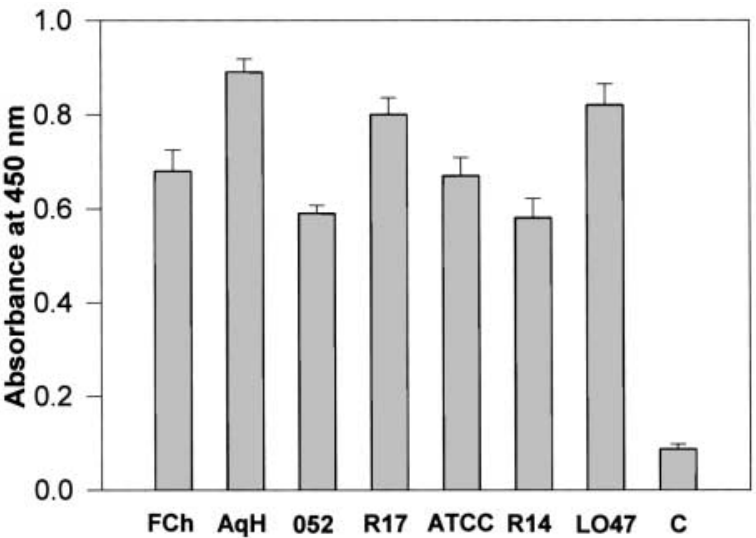

Fig. 4. Detection of different isolates of Piscirickettsia salmonis. The isolates were grown and quantified as described in 'Materials and methods'. About $100 \mathrm{ng}$ of each isolate was assayed in the ELISA and compared with the absorbance of a negative control without bacteria. The microtiter plate was activated with the antibody 2C1, and the second antibody was $7 \mathrm{G} 4$ conjugated with peroxidase. Each value is the average of 4 determinations, and the vertical bars represent the standard deviation. FCh, $\mathrm{AqH}, 052, \mathrm{R} 17, \mathrm{ATCC}, \mathrm{R} 14$ and L047 are isolates described under 'Materials and methods'. $\mathrm{C}$ is the negative control

nis. Moreover, no cross-reaction was found with other salmon pathogens (Jamett et al. 2001). Therefore, these antibodies were used to develop an ELISA test for the detection of $P$. salmonis.

The conjugation of the monoclonal antibodies with horseradish peroxidase according to the procedure of Tijssen \& Kurstak (1984) yielded a reagent with strong activity. However, with older preparations, a nonspecific increase of the absorbance of negative controls was observed. This problem was resolved by including an incubation step with glycine to quench any aldehyde left after the first reduction step. Under these conditions the reading obtained with negative samples was stable for $6 \mathrm{mo}$ at $4^{\circ} \mathrm{C}$. The mono-

Table 2. Detection of Piscirickettsia salmonis in salmon kidney samples by ELISA and comparison with indirect immunofluorescence (IFAT)

\begin{tabular}{|c|c|c|}
\hline \multirow[t]{2}{*}{ IFAT results } & \multicolumn{2}{|c|}{ ELISA results } \\
\hline & No. positive & No. negative \\
\hline Positive $\quad 54$ & 53 & $1^{\mathrm{a}}$ \\
\hline Negative 76 & 0 & 76 \\
\hline \multicolumn{3}{|c|}{$\begin{array}{l}\text { The reading of this sample was at the cut off } \\
\pm 10 \% \text { and therefore considered indeterminate } \\
\text { rather than negative }\end{array}$} \\
\hline
\end{tabular}


clonal antibody 7G4 was stable and easy to produce in large amounts, and it was selected as the secondary antibody for the assay.

From the 7 monoclonal antibodies tested in the capture step of the ELISA, only 7G4, 2C1, 6E2 and 8F5 revealed good comparable capturing activity. In contrast, the capturing activity of the antibodies 1G9, 5G1 and $7 \mathrm{G} 11$ was poor. This is an unexpected result since the latter antibodies did not differ from the former when used for immunofluorescence assay (Jamett et al. 2001). At present we have no explanation for this behavior.

An important feature of the ELISA test presented in this work is the high specificity and sensitivity of the assay. No cross-reaction was detected when the assay was run with several pathogens frequently found in salmonid fish. Moreover, $100 \%$ of the salmon kidney samples that were negative by IFAT were also negative by the ELISA test. On the other hand, 53 out of 54 positive kidney samples as determined by immunofluorescence were correctly detected by the ELISA test, resulting in $98 \%$ sensitivity. Sample 54 was also positive by IFAT, although it contained a low amount of bacteria. The absorbance obtained with this sample in the ELISA test was 0.29 , which was within the gray zone of the assay corresponding to the cut-off value $\pm 10 \%$. Therefore, the low content of Piscirickettsia salmonis in this sample is at the detection limit of the ELISA.

Another important characteristic of the ELISA test was that several isolates of Piscirickettsia salmonis were correctly detected by the assay. Since the first identification of $P$. salmonis as the causative agent of the salmonid rickettsial septicemia (SRS), several new isolates have been described in Chile as well as in other countries (Brocklebank et al. 1993, Rodger \& Drinan 1993, Grant et al. 1996, Olsen et al. 1997). We maintain in the laboratory 6 Chilean isolates obtained from kidney tissue of coho salmon and rainbow trout. These isolates were readily detected by the capture ELISA described in this work, assuring the detection of the bacteria independently of small differences that may exist among them. In conclusion, the ELISA technique reported here is useful in replacing the lengthy and labor-intensive immunofluorescence assay for $P$. salmonis identification.

Acknowledgements. This work was partially supported by Grant No. 96-0952 from FONTEC, Chile, in association with the following salmon farming industries: Inversiones Pacífico Sur, Pesquera Eicosal, Productos del Mar Ventisqueros S.A., Salmones Multiexport, Trouw Chile S.A. and Trusal S.A., and Grant P99-007-F from the MIFAB, Chile. We thank Drs Arturo Yudelevich and Mario Rosemblatt for their suggestions and interest in this work, and Juan Jeldres for salmon care.

\section{LITERATURE CITED}

Barnes MN, Landolt ML, Powell DB, Windon JR (1998) Purification of Piscirickettsia salmonis and partial characterization of antigens. Dis Aquat Org 33:22-41

Bravo SS, Campos ML (1989) Coho salmon syndrome in Chile. FHS/AFS Newsl 17:3

Brocklebank JR, Evelyn TP, Speare DJ, Armstrong RD (1993) Rickettsial septicemia in farmed Atlantic and chinook salmon in British Columbia: clinical presentation and experimental transmission. Can Vet J 34:745-748

Burzio VA, Silva T, Pardo J, Burzio LO (1996) Mussel adhesive enhances the immobilization of human chorionic gonadotrophin to a solid support. Anal Biochem 241: 190-194

Cvitanich JD, Garate ON, Smith CE (1991) The isolation of a rickettsia-like organism causing disease and mortality in Chilean salmonids and its confirmation by Koch's postulate. J Fish Dis 14:121-145

Fryer JL, Lannan CN, Garcés LH, Larenas JJ, Smith PA (1990) Isolation of a rickettsiales-like organism from diseased coho salmon (Oncorhynchus kisutch) in Chile. Fish Pathol 25:107-114

Fryer JL, Lannan CN, Giovannoni SJ, Wood ND (1992) Piscirickettsia salmonis gen. nov., sp. nov., the causative agent of an epizootic disease in salmonid fishes. Int J Syst Bacteriol 42:120-126

Gaggero A, Castro H, Sandino AM (1995) First isolation of Piscirickettsia salmonis from coho salmon, Oncorhynchus kisutch (Walbaum), and rainbow trout, Onchorhynchus mykiss, during the fresh water stage of their life cycle. J Fish Dis 18:277-279

Garcés LH, Larenas JJ, Smith PA, Sandino S, Lannan CN, Fryer JL (1991) Infectivity of a rickettsia isolated from coho salmon Oncorhynchus kisutch. Dis Aquat Org 11: 93-97

Grant AN, Brown AG, Cox DI, Birkbeck TH, Griffen AA (1996) Rickettsia-like organism in farmed salmon. Vet Rec 138:423 (Letter)

Jamett A, Aguayo J, Miquel A, Muller I and 4 others (2001) Characterization of monoclonal antibodies against Piscirickettsia salmonis. J Fish Dis 24:205-215

Lannan CN, Fryer JL (1993) Piscirickettsia salmonis, a major pathogen of salmonid fish in Chile. Fish Res 17: 115-121

Lannan CN, Winton JR, Fryer JL (1984) Fish cell lines: establishment and characterization of nine cell lines from salmonids. In Vitro 20:671-676

Lannan CN, Ewing SA, Fryer JL (1991) A fluorescent antibody test for detection of the rickettsia causing disease in Chilean salmonids. J Aquat Anim Health 3:229-234

Olsen AB, Melby HP, Speilberg L, Evensen O, Hastein T (1997) Piscirickettsia salmonis infection in Atlantic salmon Salmo salar in Norway: epidemiological, pathological and microbiological findings. Dis Aquat Org 31: $35-48$

Rodger HD, Drinan EM (1993) Observation of a rickettsia-like organism in Atlantic salmon, Salmo salar L., in Ireland. J Fish Dis 16:361-369

Smith PK, Krohn RI, Hermanson GT, Mallia AK and 6 others (1985) Measurement of protein using bicinchoninic acid. Anal Biochem 150:76-85

Tijssen P, Kurstak E (1984) Highly efficient and simple methods for the preparation of peroxidase and active peroxidase-antibody conjugates for enzyme immunoassays. Anal Biochem 136:451-457

Submitted: May 2, 2001; Accepted: October 18, 2001

Proofs received from author(s): April 2, 2002 